\title{
ANALISIS HUMAN RELIABILITY PADA OPERATOR MAINTENANCE MESIN UNTUK MENGENDALIKAN HUMAN ERROR DENGAN METODE SPAR-H DI PT. TJOKRO PUTRA PERKASA
}

\section{ANALYSIS OF HUMAN RELIABILITY ON MAINTENANCE MACHINERY OPERATOR TO CONTROL HUMAN ERROR WITH SPAR-H METHOD IN PT. TJOKRO PUTRA PERKASA}

\author{
Aditya Praswuri Wulandari \\ PT. Global Rekayasa Indonesia \\ E-mail: adityadari@gmail.com
}

\begin{abstract}
Operator have considerable contribution in the operation of the system trough its role in the completion of their work. Therefore it is important to know the operator's reliability (human reliability). The levels of human reliability is determined by calculating the potential in making mistakes, known as human error. Human error is influenced by the inadequate system design, the working bad situation, the high complexity of the work, the characteristics of human behavior, the mental and physical fatigue, the working environment and organizational policies. The main objective of this study was to analyze the reliability of the human operators to control the occurrence of human error. This study was an observational with cross-sectional approach. The study was conducted on 14 of operators maintenance machine in PT. Tjokro Putra Perkasa. Data were collected by means of interview and observation. Data were obtained using Hierarchical Task Analysis (HTA) and Standardized Plant Analysis Risk Human Reliability Assessment (SPAR-H). The result showed that most (80\%) of the operators did not wear Personal Protective Equipment (PPE), possible were widely found in preventive maintenance machine bubut, the high score (HEP $=0.0477)$ of human unreliability was found in operators working instruction in machine bubut, hobbing and CNC, as whole the system reliability was still low, and the majority (80\%) of operators were still unreliable in doing their job.
\end{abstract}

Keywords: human error, human reliability, SPAR- $H$

\begin{abstract}
ABSTRAK
Operator memiliki kontribusi yang cukup besar dalam operasi sistem melalui perannya dalam penyelesaian pekerjaan. Oleh karena itu penting untuk mengetahui kehandalan operator (human reliability). Tingkat human reliability ditentukan dengan memperhitungkan potensinya untuk melakukan kesalahan, dikenal dengan human error. Human error dipengaruhi desain sistem yang tidak memadai, situasi kerja yang buruk, tingginya kompleksitas pekerjaan, karakteristik perilaku manusia, kelelahan fisik dan mental, lingkungan kerja serta yang kebijakan organisasi. Tujuan umum dari penelitian ini adalah untuk menganalisis human reliability pada operator maintenance mesin di PT. TPP dalam mengendalikan human error dan kasus kecelakaan kerja dengan metode SPAR-H. Penelitian ini merupakan penelitian observasional dengan pendekatan cross-sectional. Jenis Penelitian dilakukan pada 14 operator maintenance mesin di PT. Tjokro Putra Perkasa. Berdasarkan sifat masalah dan analisis datanya maka penelitian ini termasuk penelitian deskriptif. Data diperoleh dari hasil wawancara dan observasi. Data yang diperoleh dianalisis dengan menggunakan Hierarchical Task Analysis (HTA) dan metode SPAR-H. Hasil penelitian menunjukkan bahwa sebagian besar (80\%) operator tidak memakai Alat Pelindung Diri (APD), possible error terbanyak ditemukan pada preventive mesin bubut sebanyak 11 possible error, nilai tertinggi $(\mathrm{HEP}=0,0477)$, secara keseluruhan kehandalan sistem masih rendah, dan mayoritas $(80 \%)$ operator tidak handal dalam melaksanakan pekerjaan mereka.
\end{abstract}

Kata kunci: human error, human reliability, SPAR-H 


\section{PENDAHULUAN}

International Labour Organization (ILO) menilai Indonesia sebagai negara dengan kecelakaan kerja yang tinggi. Penelitian yang dilakukan oleh ILO pada tahun 2009 melaporkan bahwa kecelakaan kerja di Indonesia menempati urutan ke 152 dari 153 negara yang diteliti. Hal tersebut menunjukkan masih buruknya perhatian terhadap Keselamatan dan Kesehatan Kerja (K3) di Indonesia. Data mengenai kecelakaan kerja di Indonesia pada tahun 2010 menyebutkan bahwa setiap 100.000 tenaga kerja terdapat 20 orang yang mengalami kecelakaan kerja termasuk dalam kategori fatal. Kondisi ini berdampak pada penurunan Gross National Product di Indonesia sebesar 4\% (ILO, 2010).

Dalam mengurangi tingkat kecelakaan kerja, pemerintah Kementerian Tenaga Kerja dan Transmigrasi (Kemenakertrans) telah menetapkan program prioritas yang bertujuan meningkatkan budaya K3 di Indonesia. Program yang dilaksanakan adalah "Indonesia Berbudaya K3 Tahun 2015" melalui Keputusan Kemenakertrans Nomor: Kep.372/Men/XI/2009. Program ini merupakan bentuk komitmen dari pemerintah Indonesia yang merupakan hasil kesepakatan dari 33 negara di dunia yang tertuang dalam Declaration on Safety and Health at Work (Farid, 2012).

Kesadaran akan budaya K3 pada tenaga kerja merupakan hal yang penting untuk dikembangkan. Pengetahuan dan perilaku yang aman sangat penting dalam mengurangi tingkat kecelakaan kerja. Hal tersebut memiliki hubungan yang erat terhadap faktor manusia sebagai penyebab kecelakaan kerja. Faktor manusia tersebut pernah diteliti oleh Geostech pada tahun 1999 melalui teori The Human Factors Theory of Accident yang mengungkapkan faktor manusia sebagai penyebab untuk mengidentifikasi kecelakaan kerja. Geostech menyatakan bahwa terjadinya kecelakaan kerja dikarenakan rangkaian kegiatan yang disebabkan oleh human error. Heinrinch (1980), melaporkan bahwa $85 \%$ dari total kecelakaan kerja yang terjadi di dunia disebabkan oleh faktor human error. Menurut Suma'mur (2009) bahwa rata-rata kecelakaan kerja di Indonesia mencapai 100.000 kasus setiap tahun dari 7-8 juta populasi tenaga kerja. Selanjutnya, berdasarkan hasil analisis ekonomi menunjukkan bahwa kejadian tersebut berdampak pada kerugian perusahaan ratarata Rp. 100-200 milyar per tahun. Salah satu faktor penyebab kecelakaan fatal yang terjadi pada tenaga kerja di Indonesia adalah kondisi mesin yang tidak layak operasional. Selain itu, human error diketahui menjadi faktor penyebab lain terjadinya kecelakaan fatal tersebut.

Pedoman dan pelaksanaan teknis tentang K3 di Indonesia tentang human error mengacu pada UU. No. 13 Tahun 2003 tentang Ketenagakerjaan. Undang-undang tersebut menjelaskan bahwa setiap perusahaan wajib menerapkan sistem manajemen $\mathrm{K} 3$ yang terintegrasi dengan sistem manajemen perusahaan (pasal 87, ayat 1). Sistem manajemen K3 adalah bagian dari sistem manajemen perusahaan secara keseluruhan, yang meliputi struktur organisasi, perencanaan, pelaksanaan, tanggung jawab, prosedur dan proses, sumber daya yang dibutuhkan bagi pengembangan penerapan, pencapaian, pengkajian, dan pemeliharaan kebijakan $\mathrm{K} 3$ dalam rangka pengendalian risiko yang berkaitan dengan kegiatan kerja guna terciptanya tempat kerja yang aman, efisien, dan produktif.

Berdasarkan fakta tentang kecelakaan kerja akibat human error yang terjadi di Indonesia, maka penelitian ini dilakukan untuk mencari tingkat keterkaitan antara realibilitas tenaga kerja dengan angka kecelakaan yang terjadi di perusahaan tempat penelitian. Penelitian ini dilakukan melalui beberapa tahap, antara lain identifikasi, kuantifikasi, dan reduksi kecelakaan kerja. Pengukuran reliabilitas dalam penelitian ini menggunakan salah satu metode dari Human Reliability Assessment (HRA), yaitu Standardized Plant Analysis Risk Human Reliability Assessment (SPAR-H). Metode ini memiliki keunggulan, yaitu dapat mengukur kontribusi tenaga kerja terhadap tingkat risiko kecelakaan kerja (Bell dan Holroyd, 2009). Selain itu, metode ini dapat memberi gambaran tentang probabilitas berdasarkan jenis kegiatan diagnosis dan jenis kegiatan actions.

SPAR-H merupakan teknik sederhana yang digunakan untuk mengukur tingkat keandalan kinerja manusia. Metode ini mempunyai beberapa keuntungan, antara lain memperoleh data relatif cepat, memiliki akurasi dan validitas yang tinggi, lebih mudah dimengerti dan lebih cepat digunakan dalam pengidentifikasian serta penilaian tugas operator. SPAR-H menggunakan rumus matematika yang menghasilkan nilai Human Error Probability (HEP) melalui Hierarchical Task Analysis (HTA). Menurut Smith dalam Gertman dan Blackman (2004), penghitungan ini digunakan untuk mempermudah pemecahan komponen dari setiap langkah kerja (sub task) sehingga diperoleh pemecahan masalah yang cepat dan tepat. Metode ini tidak hanya dapat mengurangi human error, namun 
juga memberi pemecahan masalah untuk proses perbaikan di semua tingkat safety. Keuntungan lain dari metode ini adalah dapat digunakan sebagai acuan dalam penyelenggaraan pelatihan (training) dan pemberian motivasi yang tepat terhadap operator (Gertman dan Blackman 2004).

PT. Tjokro Putra Perkasa Surabaya merupakan salah satu perusahaan pembuatan spare part mesin, seperti gear, shaft, dan komponen mesin lainnya. Berdasarkan fakta di lapangan menunjukkan bahwa pekerjaan di bagian maintenance peralatan berat (heavy equipment) tempat produksi spare part mesin mempunyai tingkat risiko yang tinggi. Hal tersebut dibuktikan dengan $24 \%$ kasus kecelakaan berasal dari bagian maintenance. Ada dua pendekatan yang dapat digunakan untuk mengurangi tingkat risiko kecelakaan kerja di perusahaan baik teknis maupun non teknis. Pendekatan teknis dapat dilakukan dengan pengawasan atau supervisi terhadap tugas operator sesuai dengan prosedur operasional standar atau instruksi kerja yang telah ditetapkan. Adapun pendekatan non teknis dapat dilakukan dengan memberi kenyamanan kerja terhadap operator melalui mekanisme reward and punishment secara terukur dan proporsional, penentuan jam kerja dan istirahat yang tepat, sistem penggajian yang profesional, pemberian menu gizi dan pelayanan kesehatan yang memadai.

Data tentang jumlah kecelakaan kerja yang terjadi di PT. Tjokro Putra Perkasa menyebutkan bahwa kecelakaan kerja banyak ditemukan di bagian perawatan mesin (machine maintenance). Bagian maintenance merupakan tempat bekerja para pekerja mekanik mesin dalam perawatan mesin-mesin produksi.

Berdasarkan fakta dan data tentang kasus kecelakaan kerja yang berkaitan dengan human error, maka penelitian ini dilakukan dengan metode SPAR-H untuk menganalisis keterkaitan antara Human Reliability pada operator maintenance mesin dengan tingkat human error yang terjadi di PT. Tjokro Putra Perkasa. Penelitian ini dapat digunakan untuk memberi gambaran tentang potensi terjadinya risiko kecelakaan akibat human error. Hasil penelitian ini, selanjutnya dapat digunakan sebagai rekomendasi pemberian treatment yang tepat terhadap setiap tindakan kesalahan akibat human error yang dilakukan oleh operator di bagian maintenance.

Berdasarkan latar belakang dan identifikasi permasalahan tentang kasus kecelakaan kerja akibat human error di PT. Tjokro Putra Perkasa selama tahun 2013-2014, maka penelitian ini dilakukan dengan skala prioritas mengidentifikasi dan menganalisis kasus kecelakaan kerja terhadap operator yang bertugas di bagian maintenance. Metode yang digunakan untuk mengetahui dan mengendalikan tingkat human error adalah HTA yang merupakan bagian dari metode SPAR-H. Keunggulan yang dimiliki oleh metode ini adalah dapat digunakan untuk mengetahui tingkat human error secara mudah dan cepat sehingga mampu meminimalisasi timbulnya unsafe action. Keunggulan lainnya adalah dapat memberikan gambaran secara rinci tentang langkah preventif yang harus dilakukan oleh operator dalam melaksanakan tugas di bagian maintenance serta mampu memprediksi kesalahan yang akan terjadi. Berdasarkan hal tersebut penerapan metode ini diharapkan tidak hanya memberi kenyamanan dan menekan angka kecelakaan akibat human error, namun juga memberi kontribusi penting bagi kelancaran proses produksi dan peningkatan aset perusahaan.

Penelitian ini berfokus untuk identifikasi human error pada pekerjaan maintenance mesin di PT. Tjokro Putra Perkasa, bagian tersebut terjadi kecelakaan dalam beberapa tahun terakhir yaitu pada tahun 2013 hingga 2014. Tujuan dari penelitian ini adalah untuk melakukan analisis human reliability pada operator maintenance mesin di PT. Tjokro Putra Perkasa dalam upaya mengendalikan human error dan kasus kecelakaan kerja dengan metode SPAR-H.

\section{METODE}

Penelitian ini menggunakan rancang bangun penelitian observasional. Pendekatan yang dipergunakan dalam pengambilan data adalah pendekatan kualitatif melalui observasi langsung dan wawancara mendalam (indepth interview). Berdasarkan waktu penelitian, merupakan penelitian cross sectional karena pengumpulan data sekaligus pada suatu waktu atau satu kali pengamatan (Sugiyono, 2008).

Menurut analisis, penelitian ini bersifat deskriptif, karena penelitian bertujuan utama menggambarkan atau mendeskripsikan suatu keadaan secara subjektif tentang analisis human reliability untuk upaya mengendalikan human error dengan metode SPAR-H (Gertman dan Blackman, 2004). 
Subjek penelitian yang digunakan adalah semua operator bagian maintenance yang berjumlah 14 orang dan semua dijadikan subjek penelitian. Penelitian dilakukan di PT. Tjokro Putra Perkasa di bagian maintenance dan spesifik pada mesin bubut, mesin hobbing, dan mesin CNC. Berlokasi di Jalan Berbek Industri I No. 2 Surabaya.

Variabel penelitian meliputi human reliability assessment, hierarchical task analysis, serta unsafe action. Pengumpulan data dilakukan dengan wawancara menggunakan metode indepth interview, observasi, serta data sekunder seputar kecelakaan kerja dan instruksi kerja operator maintenance mesin bubut, mesin hobbing, dan mesin CNC. Analisis data menggunakan metode HTA serta SPAR-H yang kemudian disajikan dalam bentuk narasi.

Data primer berasal dari hasil wawancara dari 14 operator maintenance mesin dan 3 expert judgment. Expert judgement terdiri dari seorang foreman, supervisor unit mesin, dan safety officer. Expert judgement adalah seseorang yang mempunyai pengalaman dan memahami dengan baik setiap instruksi kerja yang dikerjakan pada sebuah operatoran.

\section{HASIL}

Hierarchical Task Analysis untuk Langkah Kerja Preventive Maintenance Mesin Beserta Penilaian Expert Judgement

HTA memberikan gambaran yang jelas tentang langkah melakukan pekerjaan suatu task. Seorang expert judgement secara objektif memberikan penilaian tentang kesesuaian antara Standar Operasional Prosedur (SOP) yang berlaku dengan pelaksanaan task secara langsung.

Preventive maintenance mesin bubut mempunyai task pokok. Task 1 meliputi langkah awal pengerjaan preventive maintenance mesin bubut yang terdiri dari 2 sub task, kemudian berlanjut pada task 2, task 3, task 4, task 5, task 6 yang terdiri dari 5 sub task. Data yang telah diambil dari hasil observasi terlihat bahwa sebanyak 28 task pelaksanaannya sudah sesuai dengan prosedur yang berlaku, sedangkan sebanyak 4 task tidak sesuai dengan prosedur. 4 task tersebut adalah ketidaksesuaian dalam pemakaian APD secara lengkap, memeriksa roda gigi pemutar, memeriksa aksis sumbu melalui pusat perputaran roda gigi, serta memeriksa sudut heliks.

Preventive maintenance mesin $\mathrm{CNC}$ mempunyai 6 task pokok. Task 1 meliputi langkah awal pengerjaan preventive maintenance mesin $\mathrm{CNC}$ yang terdiri dari 4 sub task, kemudian berlanjut pada task 2, task 3, task 4, task 5 dan task 6 yang terdiri dari 4 sub task. Sebanyak 27 task pelaksanaannya sudah sesuai dengan prosedur yang berlaku, sedangkan sebanyak 3 task tidak sesuai dengan prosedur. 3 task tersebut adalah ketidaksesuaian dalam pemakaian APD secara lengkap, memeriksa control uni/processor, serta memeriksa sudut heliks. Pada preventive maintenance mesin bubut terdapat 3 task yang mempunyai potensi error, yaitu pada saat memeriksa gear box level oil, pelumasan head stock dan gigi-gigi transmisi, poros spindel dan cekal serta pemeriksaan roda gigi pemutar. Dari hasil observasi dapat disimpulkan bahwa terdapat 11 possible error dari langkah kerja preventive maintenance mesin bubut.

\section{Identifikasi Possible Error dari Langkah Kerja Maintenance Mesin Bubut, Mesin Hobbing dan Mesin CNC}

Penelitian ini melakukan identifikasi possible error dari langkah kerja operator preventive maintenance mesin bubut. Pada preventive maintenance mesin bubut terdapat 3 task yang mempunyai potensi error, yaitu pada aktivitas memeriksa gear box level oil, pelumasan head stock dan gigi-gigi transmisi, poros spindel dan cekal serta pemeriksaan roda gigi pemutar. Terdapat 11 possible error dari langkah kerja preventive maintenance mesin bubut serta akibat yang terjadi.

Selanjutnya dilakukan identifikasi error langkah kerja operator preventive maintenance mesin hobbing. Pada preventive maintenance mesin hobbing terdapat task yang mempunyai potensi error, yaitu pada saat pemeriksaan kondisi oli, mengecek gear box, memeriksa roda gigi pemutar, memeriksa aksis sumbu melalui pusat perputaran roda gigi, bearing serta memeriksa sudut heliks dan aksis roda gigi. Terdapat possible error dari langkah kerja preventive maintenance mesin hobbing serta akibat yang dapat terjadi.

Pada preventive maintenance mesin $\mathrm{CNC}$ terdapat 6 task yang mempunyai potensi error, yaitu pada saat pemeriksaan kondisi program, pemeriksaan kondisi listrik, pemeriksaan control unit/processor, pemeriksaan motor listrik, pemeriksaan keausan pahat, pemeriksaan kekuatan dari dudukan mesin. Data yang didapatkan dari hasil observasi menyatakan bahwa terdapat 8 possible error dari langkah kerja preventive maintenance mesin serta akibat yang dapat terjadi. Error diidentifikasi merupakan human error jenis operating error yang 
dapat menyebabkan kecelakaan kerja. Human error jenis operating error dipilih karena terfokus pada kesalahan yang berkaitan dengan personil operasi dan salah satu penyebabnya dipengaruhi oleh work instruction yang tersedia.

\section{Analisis Grafik Rekapitulasi Kehandalan Sistem}

Dari data observasi yang dilakukan peneliti maka hasil penghitungan dengan metode SPAR-H dibuat hasil akhir dengan menampilkan grafik rekapitulasi kehandalan sistem dari 3 mesin yang di teliti.

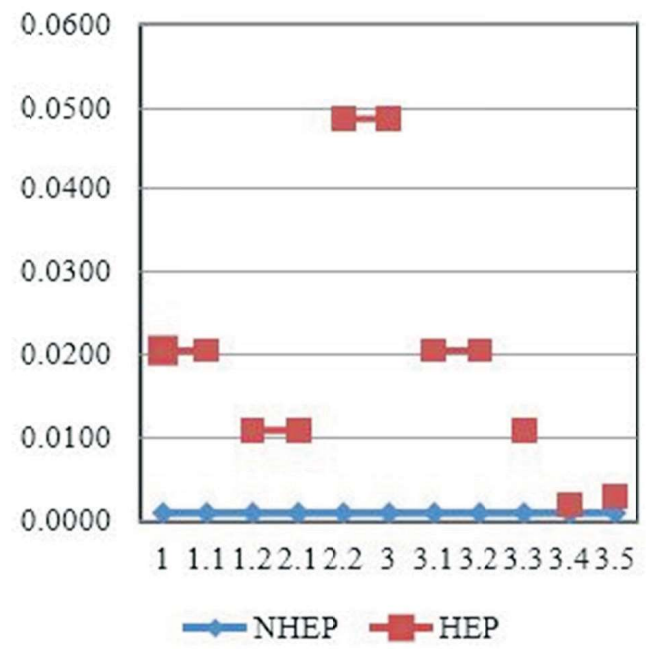

Gambar 1. Grafik Rekapitulasi Kehandalan Sistem Mesin Bubut

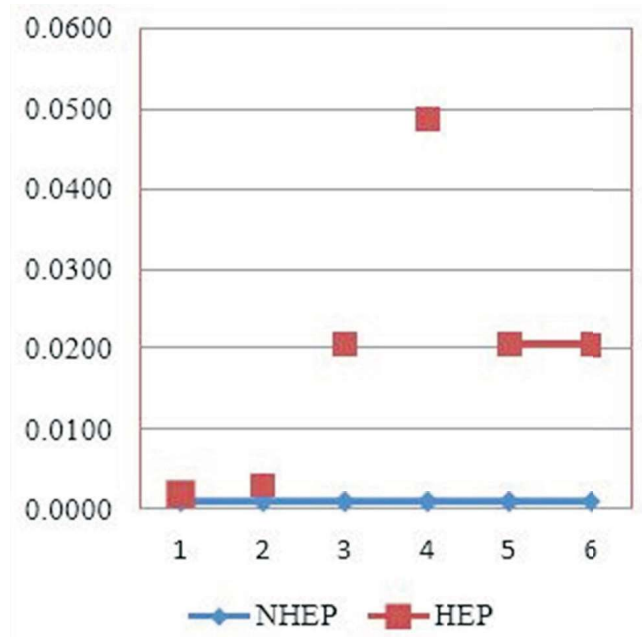

Gambar 2. Grafik Rekapitulasi Kehandalan Sistem Mesin Hobbing
Dilihat dari grafik rekapitulasi kehandalan sistem, mesin bubut memiliki 2 macam jenis task yang memiliki nilai HEP yang tinggi. Hal tersebut membuktikan bahwasanya task step 2.2 dan 3 memiliki potensi risiko kecelakaan yang tinggi. Sistem kehandalan pada mesin bubut masih kurang, karena jumlah HEP 0,0477 termasuk kategori tinggi karena jauh dari nilai yang telah ditentukan NHEP 0,0010 .

Grafik rekapitulasi kehandalan sistem, mesin hobbing memiliki 1 jenis task yang memiliki nilai HEP yang tinggi. Hal tersebut membuktikan bahwasanya task step 4 memiliki potensi risiko pada mesin hobbing masih kurang, karena jumlah HEP 0,0477 termasuk kategori tinggi karena jauh dari nilai yang telah ditentukan NHEP sebesar 0,0010. Sedang kategori task yang lainnya masuk dalam kategori sedang. Berdasarkan dari grafik rekapitulasi kehandalan sistem, mesin $\mathrm{CNC}$ memiliki 1 jenis task yang memiliki nilai HEP paling tinggi. Hal tersebut membuktikan bahwa task step 4 memiliki potensi risiko kecelakaan yang tinggi.

\section{PEMBAHASAN}

Seorang ahli keselamatan dan kesehatan kerja dapat menggunakan task analysis sebagai dasar untuk mengevaluasi desain, rencana operasional, identifikasi masalah, penambahan peralatan baru atau sebagai bagian dari tinjauan periodik (Kirwan dan Ainsworth, 1992). Task analysis dibantu dengan nomor dari teknik spesifik untuk membantu analisis, mengumpulkan data, mengelompokkannya sehingga digunakan untuk membuat keputusan desain atau bermacam-macam judgement.

Expert judgment yaitu orang atau pihak yang mengetahui permasalahan yang diangkat dalam penelitian ini. Penelitian ini menggunakan metode purposive sampling dalam pengambilan sampel expert judgement. Purposive sampling merupakan teknik pengambilan sumber data dengan menggunakan pertimbangan tertentu (Sugiyono, 2008).

Lokasi penelitian dilakukan di PT. Tjokro Putra Perkasa di bagian maintenance mesin yang berlokasi di jalan Berbek Industri I No. 2 Surabaya. Alasan memilih lokasi penelitian di PT. Tjokro Putra Perkasa adalah peneliti ingin menggali informasi tentang human error di perusahaan yang bergerak dalam bidang manufacturing dan di lokasi penelitian belum pernah dilakukan penelitian yang sejenis. 
HTA yang digunakan dalam penelitian ini yaitu berupa HTA teks, karena menampilkan hasil observasi dengan tabel yang berisi kalimat. Langkah pekerjaan utama yang akan dianalisa dengan menentukan tujuan secara keseluruhan dengan batasan-batasannya. Selain itu menentukan ruang lingkup tujuan tersebut, setiap aktivitas pekerjaan melibatkan aktivitas perawatan, aktivitas pada saat pekerjaan abnormal atau mengalami gangguan.

Memecah pekerjaan utama menjadi sub pekerjaan dan membangun plan. Plan berfungsi untuk menjelaskan rangkaian pekerjaan yang dikerjakan dengan kondisi tertentu. Selanjutnya, memberhentikan sub pekerjaan berdasarkan tingkat rinciannya. Setelah itu membuat proses penguraian tugas dan mengelompokkan beberapa sub pekerjaan.

Berdasarkan hasil penelitian, ketiga task yaitu preventive maintenance mesin bubut, mesin hobbing dan mesin $\mathrm{CNC}$ terdapat penyimpangan task yang dilakukan oleh operator, yaitu tentang penggunaan Alat Pelindung Diri (APD) yang tidak lengkap sebesar $80 \%$, ketidaktepatan dalam pembuatan laporan kepada operator lokal, ketidaksesuaian dalam pelumasan, serta pembersihan mesin. Penyimpangan-penyimpangan yang terjadi dalam task dapat memicu terjadinya human error sehingga hal tersebut harus ditangani segera dan secara cepat. Penanganan dapat berupa pelatihan, perbaikan, komunikasi, meminimalisir stres dengan memberikan proporsi istirahat yang cukup, rekayasa engineering.

Selanjutnya dalam penanganan akhir, pemecahan task dalam HTA kemudian dapat digunakan sebagai pengembangan desain proses kerja serta dasar pelatihan dan perbaikan standar operasional (Kirwan, 1995).

\section{Indentiikasi Possible Error pada Operatoran Preventive Maintenance Mesin Bubut, Mesin Hobbing dan Mesin CNC}

David (2003) menyatakan bahwa error bukanlah suatu kejadian abnormal, melainkan sesuatu yang normal terjadi atas keberadaan manusia dalam sebuah sistem kerja. Hal tersebut berbanding lurus dengan pentingnya identifikasi possible error sebagai upaya preventif untuk meminimalisasi dampak human error.

Dari upaya preventif perusahaan dalam mengurangi possible error, kecelakaan dapat dicegah dengan menghindarkan kemungkinan sebabsebabnya, orang yang paling baik bekerja adalah dengan pertimbangan yang hati-hati, berjaga-jaga dan bertanggung jawab dari setiap langkah kerjanya (Daryanto, 1986).

Pada preventive maintenance mesin bubut terdapat 3 task yang mempunyai potensi error, yaitu pada saat memeriksa level dan kondisi oli, pemberian pelumasan head stock, gigi-gigi transmisi, poros spindel dan cekal, pemberian grease pada gigi-gigi transmisi, serta pemeriksaan roda gigi pemutar. Nomor task 2.1 berupa "pelumasan head stock, gigi-gigi transmisi, poros spindel dan cekal". Task tersebut menyebabkan kemungkinan error yang dapat terjadi adalah "jari atau tangan menyentuh gigi-gigi transmisi" yang berakibat "menyebabkan tangan tergores dengan gigi-gigi transmisi dan terjepit jika gigi transmisi bergerak secara tiba-tiba. Task kedua adalah task nomor 2.2 berupa "pemberian grease pada gigi-gigi transmisi". Task terebut mempunyai possible error berupa "jari atau tangan menyentuh gigi-gigi transmisi saat mengoleskan grease" yang dapat mengakibatkan "jari atau tangan tergores gigi-gigi pemutar yang tajam".

Task ketiga bernomor task 3 "periksa gigi pemutar" yang mempunyai possible error "jari atau tangan menyentuh gigi-gigi pemutar" saat mengoleskan grease. Task tersebut dapat mengakibatkan jari dan tangan tergores gigi-gigi pemutar yang tajam. Terdapat 11 possible error dari langkah kerja preventive maintenance mesin bubut serta akibat yang dapat terjadi.

Possible error tersebut digunakan sebagai dasar perhitungan human error probability (HEP). 11 possible error tersebut adalah kejatuhan material, terbentur, terjepit, terlindas, tangan terjepit, dan terlindas eretan, tubuh pekerja lemas karena kesetrum aliran listrik.

Preventive maintenance pada mesin hobbing terdapat 6 task yang mempunyai potensi error, yaitu pemeriksaan kondisi oli, mengecek gear box, memeriksa roda gigi pemutar, memeriksa aksis sumbu melalui pusat perputaran roda gigi, bearing, dan memeriksa sudut heliks.

Potensi possible error yang tinggi kemungkinannya untuk terjadi adalah task nomor 4 yaitu "memeriksa aksis sumbu melalui pusat perputaran roda gigi". Task tersebut dapat menimbulkan possible error berupa "tangan atau jari menyentuh roda gigi pemutar" yang dapat mengakibatkan "tangan terlindas atau terjepit jika mesin berjalan secara tiba-tiba. Task yang mempunyai possible error tertinggi kedua yaitu task 
nomor 3 berupa “ periksa roda gigi pemutar". Task tersebut dapat menimbulkan possible error yaitu "tangan atau jari menyentuh roda gigi pemutar yang dapat mengakibatkan " tangan terlindas atau terjepit jika mesin berjalan secara tiba-tiba.

Possible error yang kemungkinan bisa ditimbulkan adalah terbentur, kejatuhan, tangan terjepit jika gear tiba-tiba jalan, tangan tertindas jika mesin tiba-tiba jalan, tangan tergores oleh gigi pemutar. Terdapat 6 possible error dari langkah kerja preventive maintenance mesin hobbing serta akibat yang dapat terjadi. Possible error tersebut digunakan sebagai dasar perhitungan human error probability (HEP).

Preventive maintenance mesin $\mathrm{CNC}$ terdapat 6 task yang mempunyai potensi error, yaitu pada saat memeriksa program, memeriksa kondisi listrik, memeriksa control unit/processor, memeriksa motor listrik, memeriksa keausan pahat, memeriksa kekuatan dari dudukan mesin. Terdapat 8 possible error dari langkah kerja preventive maintenance mesin CNC serta akibat yang dapat terjadi. Dari 8 possible error tersebut digunakan sebagai dasar perhitungan human error probability (HEP).

Task yang mempunyai possible error yang tinggi kemungkinan untuk terjadi adalah task nomor 4 yaitu "periksa motor listrik" yang dapat menimbulkan possible error berupa "tangan atau jari memegang motor listrik dan memegang pahat untuk mengecek kondisi mesin". Task tersebut dapat mengakibatkan "kesetrum listrik apabila mesin tiba-tiba menyala dan dapat mengakibatkan jari atau tangan terjepit dan tergores jika pahat tiba-tiba berputar".

Possible error yang kemungkinan bisa ditimbulkan pada saat melakukan maintenance mesin $\mathrm{CNC}$ adalah kesetrum aliran listrik, terjatuh akibat kaki tersandung dengan kabel yang penataannya tidak rapi, tangan terjepit control unit/processor, tangan atau jari terjepit apabila roda gigi tiba-tiba berputar.

Menurut Dewi (2002) dalam Astri (2013) operator merupakan element yang memiliki kontribusi besar dalam operasi sebuah sistem sehingga cukup penting untuk dilakukan pengukuran terhadap kehandalannya dalam melaksanakan aktivitas yang menjadi tanggung jawab operator tersebut.

Error diidentifikasi merupakan human error jenis operating error yang dapat menyebabkan kecelakaan kerja. Human error jenis operating error dipilih karena terfokus pada kesalahan yang berkaitan dengan personil operasi dan salah satu penyebabnya dipengaruhi oleh work instruction yang tersedia.

\section{Analisis Hasil Pengukuran Kehandalan Manusia pada Operator Preventive Maintenance Mesin Bubut, Mesin Hobbing dan Mesin CNC dengan Metode SPAR-H}

Analisis human error dilakukan dengan metode human reliability assessment yang diawali dengan proses pemecahan suatu operatoran (task) menjadi sub task-sub task yang lebih spesifik melalui teknik Hierarchical Task Analysis (HTA). Task Analysis (TA) yang merupakan metode formal untuk mendeskripsikan dan menganalisis interaksi manusia dengan sistem.

Analisis task mendefinisikan dengan detail peran operator dalam suatu sistem tersebut. Task analysis mendeskripsikan yang operator perlu lakukan dalam bentuk aktivitas fisik maupun kognitif untuk mencapai goal sistem.

Selanjutnya, HTA pada proses akhir menghasilkan output berupa task level dasar operator maintenance. Setelah semua task selesai di breakdown maka langkah selanjutnya adalah perhitungan kehandalan dengan metode SPAR-H. Perhitungan akhir dari metode SPAR-H akan menghasilkan nilai kehandalan dari masing-masing possible error yang dinamakan Human Error Probability (HEP). Setiap nilai kehandalan yang dihasilkan oleh masing-masing error nantinya akan memperoleh solusi, sehingga solusi yang diberikan pada teknik tersebut diharapkan dapat memberikan keluaran sebagai upaya pengendalian human error.

Setelah melakukan proses kuantifikasi melalui metode SPAR-H, proses pengukuran kehandalan manusia juga melalui tahap monitoring dan evaluasi. Hasil yang telah didapatkan perlu dilakukan monitoring dan evaluasi untuk digunakan sebagai bahan acuan pemberian rekomendasi mengenai perilaku-perilaku yang sudah aman maupun perilaku yang tidak aman serta upaya untuk memperbaiki perilaku-perilaku yang belum aman.

Pengukuran kehandalan manusia dengan metode SPAR-H merupakan metode yang sangat praktis, kategori task terwakilkan oleh nilai ketidakhandalan nominal unreability serta kondisi-kondisi yang dapat mengakibatkan error (Gertman dan Blackman, 2004).

Beberapa task pada operator maintenance mesin bubut, risiko kecelakaan terbesar dengan menggunakan metode SPAR-H adalah "bagian 
tangan dan jari memasuki area lubang roda gigi pemutar mesin bubut" (HEP sebesar: 0,0477) yaitu pada aktivitas "periksa roda gigi pemutar, periksa keausan, sobekan, dan pengelupasan". Semakin besar nilai ini maka semakin kecil nilai human reliability dari operator. Sedangkan nilai HEP terendah adalah "tangan menyentuh eretan utama (apron), eretan lintang, eretan atas (upper cross slide) saat memeriksa sambungan" (HEP sebesar $0,0010)$ yaitu pada aktivitas "periksa kekencangan eretan utama, eretan lintang dan eretan atas, periksa ada atau tidaknya pengelupasan". Nilai 0,0010 merupakan nilai yang kecil sehingga memungkinkan nilai human reliability nya semakin besar.

Pada operatoran maintenance mesin hobbing, risiko kecelakaan terbesar dengan menggunakan metode SPAR-H adalah "memeriksa aksis sumbu melalui pusat perputaran roda gigi" (HEP sebesar 0,0477 ) yaitu pada aktivitas "periksa aksis sumbu melalui pusat perputaran roda gigi, apabila kering lakukan penambahan grease". Semakin besar nilai ini maka semakin kecil nilai human reliability dari operator. Sedangkan nilai HEP terendah adalah "memeriksa kondisi oli" (HEP sebesar 0,0010) yaitu pada aktivitas "periksa kondisi oli". Nilai 0,0010 merupakan nilai yang kecil sehingga memungkinkan nilai human reliability nya semakin besar.

Dari beberapa task pada operatoran maintenance mesin CNC, risiko kecelakaan terbesar dengan menggunakan metode SPAR-H adalah "memeriksa motor listrik, memeriksa secara visual apabila ada kabel atau bagian alat yang korslet" (HEP sebesar 0,0477 ) yaitu pada aktivitas "periksa motor listrik". Semakin besar nilai ini maka semakin kecil nilai human reliability dari operator. Sedangkan nilai HEP terendah adalah "memeriksa program" (HEP sebesar 0,0010 ) yaitu pada aktivitas "periksa kondisi program". Nilai 0,0010 merupakan nilai yang kecil sehingga memungkinkan nilai human reliability-nya semakin besar.

Jika dibandingkan nilai HEP yang diperoleh, besar kecilnya HEP melalui pengukuran dengan menggunakan metode SPAR-H sangat ditentukan pemilihan generik task yang menentukan karakteristik umum dari setiap pekerjaan.

\section{Kehandalan Sistem}

Berdasarkan pengukuran diperoleh hasil HEP yang bermacam-macam jumlah perhitungannya. Risiko kecelakaan kerja terbesar dihasilkan pada aktivitas pekerjaan dengan nilai HEP 0,0477 di mesin bubut yaitu pada saat bearing dengan aktivitas mengidentifikasi putaran, suara dan keausan roda gigi pemutar.

Aktivitas kedua yang mempunyai nilai HEP 0,0477 adalah mengecek keausan dengan memasukkan jari atau tangan menyentuh roda gigi pemutar dan memberikan grease. Sedangkan nilai HEP terendah yaitu 0,0010 pada aktivitas maintenance mesin bubut berupa aktivitas "periksa kekencangan eretan utama (apron), eretan lintang dan eretan atas dengan memeriksa ada atau tidaknya pengelupasan.

Pada mesin hobbing nilai HEP tertinggi berjumlah 0,0477 , merupakan aktivitas "memeriksa aksis sumbu melalui pusat perputaran roda gigi", karena jari atau tangan menyentuh roda dengan mengoleskan grease. Risiko yang ditimbulkan berupa tangan terlindas atau juga dapat menyebabkan tangan terjepit jika mesin berjalan secara tiba-tiba. Sedangkan dari mesin CNC nilai HEP diperoleh sebanyak 0,0477 merupakan aktivitas "memeriksa motor listrik", karena tangan atau jari memegang motor listrik untuk mengecek kondisi mesin. Risiko kecelakaan kerja yang dapat ditimbulkan adalah kesetrum listrik apabila mesin tiba-tiba menyala.

Dilihat dari hasil data yang telah diolah, bahwasanya ada 2 mesin yang mempunyai possible error nya tinggi. Perhitungan kehandalan sistem berfungsi untuk melihat nilai kehandalan secara keseluruhan dari sebuah operatoran. Hasil perhitungan yang diperoleh digunakan untuk menilai sejauh mana perfomansi kehandalan manusia alami sistem kerja dan mengevaluasi perbaikan apa yang dapat dilakukan berdasarkan probabilitas kegagalan masing-masing aktivitas (Kirwan, 1994).

Upaya preventif yang dilakukan perusahaan untuk mengurangi possible error adalah memberi tanggung jawab instruktur (pengawas pekerjaan) dalam memberi instruksi dengan benar, tepat, aman untuk tiap-tiap bagian yang akan dikerjakan, menyelidiki sebab terjadinya kecelakaan dan kerusakan, melaporkan segera bilamana terjadi kecelakaan, kerusakan pada mesin dan dicatat peristiwa-peristiwa tersebut.

Keamanan bekerja sebagian besar tergantung dari tempat dan suasana sekitarnya karena tempat selalu dibutuhkan semua benda dan benda terletak pada suatu tempat, dan penyusunan/suasana tempat bekerja itu adalah relatif, tetapi perusahaan relatif mempunyai pedoman jalan yang menghubungkan antara tempat satu dengan yang lain harus terlihat jelas, rintangan yang menuju ke tempat bahaya harus terlihat jelas. Perlindungan untuk bagian-bagian dari 
mesin yang bergerak atau yang berputar. Jangan duduk, meletakkan tangan atau menginjakkan kaki pada tempat yang membahayakan, membiarkan benda kerja, alat-alat potong, berserakan di sekitar tempat kerja. Meletakkan peralatan pembantu yang mudah dijangkau misalnya pemadam kebakaran, kotak P3K, bel bahaya dan lain-lain yang sangat dibutuhkan pada keadaan gawat, sehingga orang dapat dengan mudah menemukannya.

Kehandalan operator yang rendah disebabkan oleh banyaknya faktor yang berpengaruh, seperti moral kerja yang rendah, disiplin kerja yang rendah, kurangnya pengetahuan tentang risiko yang mungkin terjadi pada saat operatoran. Sebab-sebab tersebut muncul dari dalam ataupun dari luar operatoran.

Kehandalan operator yang tinggi merupakan wujud dari kepatuhan operator dalam melaksanakan tugas yang diberikan. Selain cukupnya pengetahuan, operator memiliki moral kerja yang tinggi sehingga error yang mungkin terjadi dapat dihindari ataupun diminimalisir sedini mungkin.

Pengukuran dengan metode SPAR-H terdapat failure probabilities yang terdiri atas action failure probabilities yang digunakan untuk kegiatan yang bersifat actions dan diagnosis failure probabilities yang digunakan untuk kegiatan yang bersifat diagnosis. Action failure probabilities merupakan probabilitas terkecil kemungkinan terjadinya human error. Pada penelitian ini keseluruhan pekerjaan yang diamati merupakan pekerjaan yang bersifat action dan diagnosis sehingga pada penelitian ini nilai failure probabilities yang digunakan adalah sebesar 0,001 dan 0,0010. Sehingga hasil HEP sangat ditentukan oleh penetapan Performance Shaping Factors (PSFs) yang terdiri atas 8 kriteria dan nilai untuk masing-masing multiplier untuk kriteria tersebut.

\section{SIMPULAN}

Identifikasi dari langkah aktivitas operator maintenance mesin dengan metode HTA memberikan gambaran bahwasanya terdapat penyimpangan-penyimpangan task yang dilakukan oleh operator yaitu ketidaksesuaian dalam pemakaian APD sebesar $80 \%$. Identifikasi possible error paling banyak ditemukan pada preventive maintenance mesin bubut sebanyak 11 possible error.

Pada mesin hobbing sebanyak 6 possible error, dan pada mesin CNC berjumlah 8 possible error. Human Error Probability tertinggi ditemukan pada operator maintenance mesin bubut yang pelaksanaan instruksi kerjanya masih rendah. Dari 3 peralatan mesin yang diteliti, terdapat 2 peralatan yang kehandalan operator untuk melaksanakan instruksi kerjanya termasuk dalam kategori rendah yaitu mesin bubut dan mesin hobbing.

\section{DAFTAR PUSTAKA}

Anizar. 2009. Teknik Keselamatan dan Kesehatan Kerja di Indutri. Jakarta: Graha Ilmu.

Astri, Arini. 2013. Analisis Human Reliability pada Operator Bagian Maintenance Mesin 2 untuk Mengendalikan Human Error dengan Metode Human Error Assessment and Reduction Technique (Studi kasus pada PT. PJB Unit Pembangkitan Paiton tahun 2013).

Bell, Julie \& Justin Holroyd. 2009. Review of Human Reliability Assessment Methods. Health and Safety Laboratory. Buxton: Hapur Hill.

Daryanto. 1986. Teknik Pemeliharaan Mesin dan Keselamatan Kerja Bengkel. Bandung: Tarsito, 84-85.

David, D. Woods. 2003. Behind Human Error: Taming Complexity to Improve Patient Safety. Institute or Ergonomics: The Ohio State University.

Farid. 2012. Reliability Assessment sebagai Upaya Pengurangan Human Error dalam Penerapan Kesehatan dan Keselamatan Kerja. Skripsi. Jakarta: Universitas Indonesia, 1-140.

Gertman, D., dan Blackman, H. 2004. The SPAR-H Human Reliability Analysis Method. Idaho National Laboratory.

Heinrinch H.W., Peterson D., \& Roos N. 1980. Industrial Accident Prevention, 5th Edition. New York: McGraw-Hill.

ILO. 2010. Standar Internasional Migrasi Ketenagakerjaan. Cianjur: IMR Press.

Kirwan, Barry and L.K Ainsworth. 1992. A Guide to Task Analysis. United Kingdom: Taylor and Francis Inc.

Kirwan, Barry. 1994. A Guide to Practical Human Reliability Assessment. London: CRC Press.

Kirwan, Barry. 1995. The Validation of Three Human Reliability Quantification TechniquesTHERP, HEART, and JHEDI: Part 1- Technique Descriptions and Validation Issues.

Sugiyono. 2008. Metode Penelitian Kuantitatif Kualitatif dan $R \& D$. Bandung: Alfabeta.

Suma'mur. 2009. Higiene Perusahaan dan Kesehatan Kerja. Jakarta: Sagung Seto. 